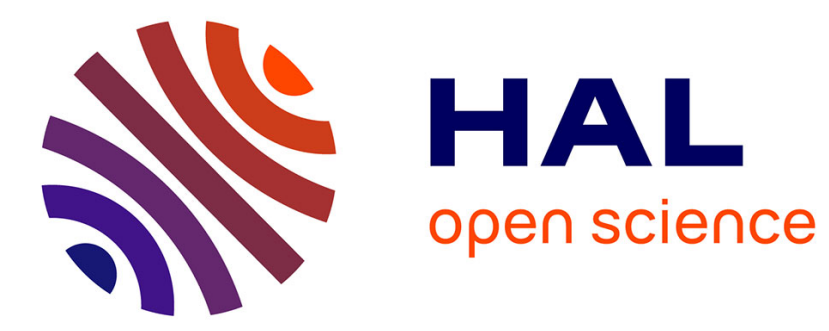

\title{
The WFD Dreams: between ecology and economics
}

Gabrielle Bouleau

\section{To cite this version:}

Gabrielle Bouleau. The WFD Dreams: between ecology and economics. Water and Environment Journal, 2008, 22 (4), pp.235 - 240. 10.1111/j.1747-6593.2008.00122.x . hal-00749874

\section{HAL Id: hal-00749874 \\ https://hal.science/hal-00749874}

Submitted on 8 Nov 2012

HAL is a multi-disciplinary open access archive for the deposit and dissemination of scientific research documents, whether they are published or not. The documents may come from teaching and research institutions in France or abroad, or from public or private research centers.
L'archive ouverte pluridisciplinaire HAL, est destinée au dépôt et à la diffusion de documents scientifiques de niveau recherche, publiés ou non, émanant des établissements d'enseignement et de recherche français ou étrangers, des laboratoires publics ou privés. 
Bouleau, G. 2008 Water and Environment Journal 22 (4): 235 - 240.

The WFD dreams: between ecology and economics.

Gabrielle Bouleau ${ }^{1,2}$

${ }^{1}$ Cemagref, UMR G-EAU, France

${ }^{2}$ Berkeley, LAEP, University of California

\begin{abstract}
The enactment of the Water Framework Directive (WFD) in the European Union triggers intense activity among Member States and raises some criticisms. The good status of waters may include an ecological dream that is difficult to achieve. Moreover, criteria for derogations require strong economic arguments. This challenge raises the debate whether the WFD is part of an incremental process, embedded in prior European water law, with feasible goals, or whether it is a dramatic change of policy towards an ecological dream which emerged during late negotiations, therefore hardly achievable. I will state that although the high ecological ambition of the WFD is unprecedented within the EU's water law, it has several precedents in other arenas, notably long enforced in the United States of America. I will argue that the major challenge of the directive is the combination of the ecological dream with an economic ideal, which has no equivalent in the US.
\end{abstract}

\title{
Key words
}

Biodiversity, Conservation, European Directive, Planning, River Basin Management, Water Framework Directive, Policy

\section{Introduction}

Established on 23 October 2000, the Directive 2000/60/EC of the European Parliament and of the Council of Ministers, also known as the Water Framework Directive (WFD), provides a framework for Community action in the field of water policy. It requires the EU Member States to bring (and maintain) their surface water bodies to a "good ecological status" (GES), and simultaneously a "good chemical status" (GCS). Derogations to a GES are possible for water bodies defined as "heavily modified" or "artificial". Water bodies are considered "heavily modified" by human impacts when the costs of alternatives are disproportionate. "Artificial" water bodies, by definition, are those made by humans. What is cutting edge in the WFD directive is that it considers only two possibilities for aquatic systems: Water bodies are either impacted by acceptable services, or they should achieve the "good surface status" (i.e. both the ecological status and the chemical status should be good). The services are regarded as acceptable under the WFD criteria when replacing them by an alternate solution will induce disproportionate costs. There is no room for "good surface status" (GSS) to be undesirable, or poorly profitable impacting services to be desirable. The GSS is the desirable and achievable dream of the WFD. The impacts that prevent water bodies from achieving the good ecological status must match an economic demand and target the full pricing. It must be 
added that the WFD includes provisions for dealing with the technical unfeasibility of restoration (unsuitable natural background, extreme events ...) but they remain limited. Emerging is the challenge that many human impacts affect the ecological status of water bodies, but do not fall within the preceding economic definition of heavy modifications. In such cases, achieving a good ecological status appears to be very uncertain (Holzwarth 2002; Moss 2003; Mostert 2003; Roche, Billen et al. 2005). In this context, some critical actors claimed that the ecological dream of the WFD was inappropriate to the European long-settled landscape. They argued that the reference to an undisturbed situation is irrelevant and sets unfeasible goals.

The feasibility of the WFD ecological provisions appeared all the more uncertain since recent works on the origins of the WFD underscored its unprecedented ecological ambition. Exploring the evolution of water issues at the EU level, scholars typically developed two narratives, incremental versus chaotic. The incremental narrative focused on the evolution of the European water law prior to the WFD enactment from 1975 to 1995 (Kallis and Nijkamp 2000; Kallis and Butler 2001; Aubin and Varone 2002; Barraqué 2002; Kaczmarek 2006). It accounted for the consistence of the WFD with previous water directives as far as environmental objectives were concerned. However it considered that the ecological objectives were unprecedented. The chaotic narrative focused on the directive negotiation from 1996 to 2000 (Aubin and Varone 2002; Kaika and Page 2003; Page and Kaika 2003; Kaika 2004). It accounted for the strong lobbying movement of ecologists and the Parliament's empowerment during the legislative negotiation. It held that the ecological ambitions of the WFD were highly unpredictable and lately introduced. Both perspectives supported the idea that the WFD ecological dream had no equivalent. Incidentally such a statement supported the critics mentioned above. Without possible comparison, the WFD would boldly go where no man has gone before. Feasibility would be all the more uncertain.

Yet both explorations restricted their scope to the water sector and at the European level. I propose to enlarge the scope outside the water sector, or beyond and below the European level. I will show that there have long been equivalents of the WFD ecological dream as worded in the WFD with concepts as: "reference sites", "ecological status", and "environmental objectives". I will argue that finding similar concepts in another context will provide both interesting comparisons and useful feedbacks from which to draw insights into the feasibility question. In the first part of the paper, I will first resume the EU acquis in order to show that ecological goal-setting have existed in the European Community since 1979. I will then address the scope of the WFD negotiation, in order to assess what it did and what it did not change. In a third part, I propose to compare the WFD with some elements of the United States law that have been enforced. Last, I will discuss the differences between the US provisions and the WFD to conclude on the very nature of the WFD challenge.

\section{The EU acquis prior to the WFD}

The WFD is not the first European legislation on water quality. Twenty-eight directives addressing water quality were adopted prior to it not to mention sister directives. Water experts concur in describing two historic waves of legislation which follow each other with an inner logic. In this paragraph, I will argue that the attention paid to the growing European water law (1) was valuable to account for the consistence of EU water law, but (2) it failed to notice that the water sector has been relatively impervious to ecological concerns despite a growing ecologist movement in the EU since the late 80s. This gap was bridged by the WFD 
which therefore appears like a big shift. In contrast, the EU nature conservation law incorporated ecological requirements much earlier.

European analysts typically hold that the WFD inherited from two waves of European law in water quality. The first one happened aimed at protecting consumers' health; the second one followed, between 1988 and 1995, and promoted broader command and control based on an integrated approach (Kallis and Nijkamp 2000; Aubin and Varone 2002; Barraqué 2002; Kaczmarek 2006). But both waves set environmental objectives rather than ecological ones (Howarth 2006).

The first legislative wave introduced reporting requirements. It empowered the public by opening access to administrative data and fostered progress in monitoring technologies. The directives on fish, shell farming and aquatic pollution prevention were poorly translated in national regulations (Kallis and Nijkamp 2000). The other directives (water for drinking purposes, water for swimming, pollution caused by certain dangerous substances and groundwater preservation) paved the way for the second legislative wave based on the integrated approach.

For European experts on water, the second wave stemmed from an inter-governmental workshop on the European Community policy for water held in Frankfurt in June 27 and 28, 1988. Two years before, the Rhine happened to be dramatically polluted by the accident of Sandoz. Confronted to the downstream polluted flow, the Dutch population feared a lack of drinking water supply. Other Europeans suddenly discovered on their television screens that the Rhine was transporting tons of dead fish. Environmentalist politicians gained power in riparian countries (Lodge 1989; Vogel 2005). They influenced positions of the Council of Ministers. At the end of the Frankfurt workshop, the European Council of Ministers asked the Commission to submit proposals likely to improve the ecological quality of European waters. According to Aubin and Varone (2002), this was the impetus for three directives based on an integrated approach: the urban waste water directive, the directive on nitrates, and the directive controlling industrial pollution, known as IPPC. All three require the designation of environmental quality objectives, action planning to reach the objectives and restriction on polluting activities.

In this perspective, the WFD appears as a third wave of legislation addressing the ecological quality for the first time. Indeed, in the field of water management, environmentalists only succeeded in introducing ecological objectives during the negotiation of the WFD, because they benefited from the negotiation procedure as I will develop in the next part. This does not mean that the concept of ecological objectives did not exist before.

Substantive ecological input for goal-setting was adopted in the European Community legislation earlier in the sector of nature conservation (Bouleau 2007). For twenty years before the WFD, the Bird Directive (79/409/EEC) has required the preservation of naturally occurring birds in the wild state. It sets environmental objectives. It requires the assessment of the biological status of the species listed in its annexes. I argue that this directive was the first European legislation protecting the environment for its own sake. It was limited to threatened species and was based on an organismic vision of ecological communities (Richardson 1980). Then the Habitats Directive (92/43/EEC) expanded the scope of protection to functional biodiversity throughout an open network of sites (Pinton 2001). I therefore conclude that an ecological dream can be tracked back in the European legislation as early as 1979 with the Bird Directive. Ecologists may have influenced the content of the WFD much more than the content of former directives, yet they have been promoted the dream of a better ecological status in the European Community for long. As I will now argue in the following paragraph, the ecologist influence over the WFD can not be reduced to the ecologist lobbying at the Parliament during the negotiation. The articulation of water quality with "normal" values of biological elements was already set. 
136

137

138

139

140

141

142

143

144

145

146

147

148

149

150

151

152

153

154

155

156

157

158

159

160

161

162

163

164

165

166

167

168

169

170

171

172

173

174

175

176

177

178

179

180

181

182

183

The role of environmentalists during the WFD negotiation was well studied by political scientists. They brought compelling statements showing that the political context of the European arena was, and still is, very uncertain. It resulted in unexpected trade-offs (Richardson 1994). The co-decision rule made the situation even more uncertain since it empowered the European Parliament to veto the Council of Ministers's amendments (Kaika and Page 2003). Authors considered that the crucial negotiations of the WFD opposed Member States (Council of Ministers) on the one hand, and a coalition of the Parliament and the Commission on the other hand (Kallis and Butler 2001; Aubin and Varone 2002). They found that the Parliament had proven exceptionally active and very sympathetic to the aspirations of the environmentalists (Judge 1993; Kallis and Nijkamp 2000).

In the following paragraph, I will first argue that the activism of the Parliament and environmentalists (Earnshaw and Judge 2005) counterbalanced industrial lobbying but they hardly introduced any conceptual innovation. The directive proposal was initially framed by the Commission and its ecological rationale remained unchallenged. Then, I will defend that Member States and industrial lobbies did not contest the ecological relevance of the directive because there was substantial evidence of the feasibility of its implementation. Most concepts had been already implemented in some European countries.

Kaika and Page (2003) reported in details the process of readings and amendments by both the Council of Ministers and the European Parliament from 1996 to 2000. My goal in this paper is not to relate all their findings but to use them to identify the scope of the debate between the Council and the Parliament. The authors pointed out four significant issues that were at stakes. The Parliament wanted binding environmental objectives whereas the Council "proposed that the directive should 'request' that MS 'make an effort' to achieve the good surface status". The Parliament wanted short implementation deadlines (ten years) whereas the Council required twenty to thirty years. They disagreed on the phase-out of hazardous substances. The Council rejected the zero emission approach. Last, the Parliament wanted to introduce full-cost pricing as a strategy for managing water demand whereas the Council was reluctant. Obviously, the points of disagreement did not include the definition of "good ecological status," nor the reference to undisturbed conditions.

Two reasons may explain why these concepts were not challenged. One is that 'green' Member States were in favour of these concepts. Another reason is that other Member States did not find an economic justification that could fit in the general framing.

The ecological dream - ecological quality being desirable and achievable - was familiar at least to the German and to the Austrian. Since 1971, the German programme for the environment has defined criteria of ecological balance and water pureness (Defrance and Jeuffroy-Niehues 1992). The ecological integrity has been established in the Austrian Water Laws since 1985 (Moog and Chovanec 2000). The ecological dream was probably also supported by other EU 'green leaders', as political scientists called them (Borzel 2000; Jordan and Lenschow 2000; Bursens 2002). Germany, Denmark and the Netherlands together with, since 1995, Sweden, Finland and Austria held sufficient votes to block qualified majority voting decisions in the Council (Liefferink and Skou-Andersen 2005). However, little evidence exists on the effectiveness of the coalition during the WFD elaboration. Beyond 'green leaders' several Member States had adopted ecological monitoring for assessing rivers from the biota.

What is significant is that before the negotiation of the WFD started, the Commission proposed in 1993 a framework directive on the ecological quality of freshwaters (COM (93) 680) which was later resumed in the proposal of 1996. This initial proposal defined ecological water quality as the overall expression of the structure and function of the biological 
community, also taking into account physical and biological integrity of waters. Its wording and content came closer to the ones of the WFD than anything previously seen in the EU water legislation. It mentioned the pureness of water, the wildlife diversity, the ecological quality of waters, and it required goal-setting for all waters. Later discussions tuned the practical implementation of such concepts but did not reconsider them.

For those who did not agree with the ecological dream, they had to defend the opposite position, i.e. that the ecological quality of WB was not always desirable or that something else economic benefits. Political scientists demonstrated that the history of the creation of the European Union is one of a common market. Environmental issues and health protection came as a second goal in the political agenda of the European Communities (Hildebrand 2005). Social, cultural, moral issues were so different from one country to another that it had shown to be very difficult to build a coalition on them. Provisions were included for defining less stringent objectives which had to be justified by economic considerations. No Member State raised the question of the achievability of the good ecological status, because some knew they would largely advocate having heavily modified waters and others knew they could achieve the goal.

To conclude this part, I will say that the initial framing of the directive as proposed in the 1993 draft already included the ecological dream. It matched the aspirations of at least some stakeholders and did not provide much room for objections in a market-driven context. I will now argue that concepts and aspirations for an ecological dream emerged in the 1970s and have long been implemented in the US legislation. This may provide fruitful comparisons for future studies.

\section{The American example}

Whether the American example had a direct influence on the WFD provisions is beyond the scope of this article. My intent is to find similarities and anteriority which may provide interesting feedbacks. Nevertheless, there are significant elements acknowledging the indirect influence of American ecologists (Carson 1962; Meadows and Club de Rome 1972) on the global political agenda since the sixties. Social scientists hold that the student social movement of 1968, which was born in the United States, was the beginning of environmentalism in all developed countries (Rootes 1999). Moreover, political scientists have developed compelling arguments stating an influence of the US legislation on the European policy-making (Vogel 1997; Löfstedt, Vogel et al. 2001). While scholars have studied many different domains of regulation (Jordan 2005), they hardly undertook a US versus EU comparative on the evolution of the water law. This may be due to the lack of a European consistent water law until the recent WFD. In contrast, the US enacted a Clean Water Act (CWA) as early as 1972. For scholars tracing regulatory innovation, the 'old' US water legislation was probably not regarded as cutting-edge. In addition, when regulations were compared, scientists looked for similarities within a decade. The time lag between the CWA and the WFD may have prevented comparison. Yet, bringing close together the US Clean Water Act enacted in 1972 and the WFD adopted 28 years later, one can see striking conceptual similarities.

Comparing the CWA to the WFD reveals at least five common notions: references, goalsetting, criteria for down-grading standards, provision for no further degradation and undesirable substances.

The first, and the most interesting for the purpose of this paper, refers to the unimpacted reference. The CWA requires biological monitoring to assess the ecosystem integrity of waters. This integrity is defined by the biological composition of sites in pristine conditions or 
without human impacts. This language is closed to the one used in the Annex V of the WFD defining the ecological status. Concerning goal-setting, waters within the scope of the US legislation should be achieved water quality standard in order to sustain designated uses. Such uses should include swimming and fishing. Besides, since the Endangered Species Act was enacted in 1973, the federal agencies have required the designated uses to target the ecological integrity of endangered species habitats. This sounds like the requirement for a good surface status in the WFD. Because the CWA has been in place for about 35 years with a target of final phase II implementation of 2008, the time frame of the WFD may appear much narrower. Indeed the good surface status has to be achieved by 2015. But possible derogations may extend the deadlines up to 2027. Moreover the CWA in 1972 included new requirements for waste water treatment. Similar provisions have already been required by former directives.

Concerning criteria for setting less stringent goals, in the US legislation, the economic criterion that may justify down-grading goals is when achieving the high quality standard would involve widespread social and economic costs. But one must notice that three criteria of feasibility are also considered: when irreversible human-caused conditions prevent the attainment of a higher standard; when what is needed to attain the standard would cause substantial environmental damage; and when natural background conditions prevent attainment. Altogether the economic and the three technical criteria echo the WFD language.

The no further degradation requirement is a provision that appears in both legislations.

The last element I want to mention is the common provision for suppressing undesirable substances from the waters.

From the above list of conceptual resemblances, I conclude that the ecological dream pursued by the WFD is very close to what the US have tried to achieve for thirty years.

\section{The American difference}

I shall now look at other provisions of the CWA. Indeed I believe that the remaining differences between both regulations are extremely important to consider. I will focus on three: the scope, the planning process and the binding conditions.

Considering the scope, the WFD applies to freshwater and groundwater. If the ecological provisions only apply to surface waters, the good chemical status is also required for groundwater. In contrast, the CWA concerns the US waters, namely the navigable waters. If the US Supreme Court has expanded the scope of navigable waters to the tributaries and the related groundwater (Sax, Thompson Jr et al. 2006), groundwater overdraft remains beyond the scope of the CWA whereas it should not happen under the WFD. In addition, the WFD targets all kind of degradation whether the source is point or non-point. US Federal agencies instead have no legal competencies for addressing non-point pollution. The scope of the WFD is therefore broader.

Concerning the planning process, the WFD provides that Member States shall plan the combination of the best efficient measures to restore all water bodies of the same hydrographical district. Moreover the EU does not intend to fund restoration projects. Part of the WFD economic dream is that water services should cover costs including environmental ones. The CWA has no equivalent strategic requirement. Although restoration projects in the US are often subjected to cost-effectiveness appraisal on a project by project basis, strategic planning at the scale of a catchment is almost never required in the US. Moreover costrecovery is hardly demanded to US water services.

Last, I will now compare the binding conditions of both water laws, which go beyond legislative acts. I need to address the political structure of the US federation and the originality of the EU system. The US Congress sets goals to federal agencies and obligations 
for other parties under the federal rules. On the one hand, the performances of federal agencies are regularly appraised and administrative sanctions may be voted by Congress in case of failure. On the other hand, obligations of other parties under federal laws are enforced by courts. What is authorized and what is not evolves under Common Law. But at least a compelling causal relationship must be established by the court before any party be charged for the degradation of US waters. Consider the recent case on the Californian Delta smelt. The endangered smelt population is protected under federal law. Many factors impact the threaten fish including non-point pollution and pumping devices (Lund 2007). More than once, the Supreme Court summoned a federal agency to stop pumping to preserve the smelt. But it could do nothing against the non-point pollution. The smelt population may die from nonpoint pollution and nobody may be charged for it. In contrast, the EU directives set goals to the Member States (Porta 2006). No causal relationship is needed to assess whether Member States achieve EU goals or not. Whoever is responsible for the failure, Member States are likely to be charged for it. It is left to them to act accordingly in changing their domestic rules or incentives in order to achieve the goals. Member States are legally bound to perform effectively. Imagine the delta smelt case in the EU context, the State of California could be charged for the delta smelt being killed by non-point pollution. European Member States bear the burden of proving that it may have been unfeasible to avoid such a failure. Otherwise they are subjected to penalty payments. Since 1997, three penalty payments have been imposed. No case involved non-point pollution though. It may be too soon to conclude whether the EU will succeed to reduce non-point pollution by economic incentives on Member States. But this can be regarded as another element of the WFD economic dream.

While the WFD targets a broader scope of waters than the CWA, it is also much more demanding concerning the efficiency of public funds: water consumers should cover the costs; restoration projects should be consistent basin-wide.

\section{Conclusion}

It cannot be argued that the ecological dream of the WFD was furtively introduced by environmentalists during the negotiation of the directive without consideration whether it could apply to Europe. Corresponding ecological concepts and aspirations have long existed in the United States, in the EU legislation for nature conservation, and in some Member States domestic legislations. This advocates for such a dream being reasonable, at least in some places. It also provides a valuable set of possible comparisons in order to identify most costeffective measures. What may be much more challenging in the realization of the WFD is its economic dream mainly, which arose from stringent obligation upon Member States, and which has no equivalent. The economic provisions prevent contradictory investments, promote most cost-effective measures and target incentive pricing. On the long run, European environmental and economic engineering may benefit from such provisions on the promising world market for restoration.

\section{Acknowledgements}

The comparison between the EU and the US water law has been supported by Cemagref. I am very thankful to Nadine Soubotin for her revising work. I am also grateful to the anonymous reviewers for their very constructive comments which helped me to clarify my whole argument.

\section{References}


Aubin, D. and F. Varone (2002). European Water Policy. A path towards an integrated resource management. Louvain-la-neuve, EUWARENESS: 28.

Barraqué, B. (2002). Objectifs et enjeux de la DCEE. Les enjeux de la directive cadre européenne sur l'eau, Paris, 29 et 30 avril 2002.

Borzel, T. A. (2000). "Why there is no 'southern problem'. On environmental leaders and laggards in the European Union " Journal of European Public Policy 7(1): 141 - 162.

Bouleau, G. (2007). La gestion française des rivières et ses indicateurs à l'épreuve de la directive cadre. Thèse de doctorat Sciences de l'environnement. Paris, AgroParisTech - ENGREF: 457.

Bursens, P. (2002). "Why Denmark and Belgium Have Different Implementation Records: On Transposition Laggards and Leaders in the EU." Scandinavian Political Studies 25(2): 173-195.

Carson, R. (1962). Silent spring. Boston, Massachusetts, USA, Houghton-Mifflin.

Defrance, J. and I. Jeuffroy-Niehues (1992). Tradition culturelle et expertise. La Terre Outragée - Les experts sont formels. J. Theys and B. Kalaora. Paris, Autrement: 188201.

Earnshaw, D. and D. Judge (2005). "No simple dichotomies: Lobbyists and the European Parliament."

Hildebrand, P. M. (2005). The European Community's Environmental Policy, 1957 to '1992': From Incidental Measures to an International Regime? Environmental Policy In The European Union. A. Jordan, Earthscan: 19-41.

Holzwarth, F. (2002). "The EU Water Framework Directive-a key to catchment-based governance." Water Science \& Technology 45(8): 105-112.

Howarth, W. (2006). "The Progression Towards Ecological Quality Standards" Journal of Environmental Law 18(1): 3-35.

Jordan, A., Ed. (2005). Environmental Policy In The European Union, Earthscan.

Jordan, A. and A. Lenschow (2000). "Greening the European Union: what can be learned from the leaders of EU environmental policy?" European Environment 10(3): 109 120

Judge, D. (1993). Predestined to save the earth: the Environment Committee fo the European parliament. Predestined to save the earth: the Environment Committee fo the European parliament, Routledge 186-212.

Kaczmarek, B. (2006). Un nouveau rôle pour les agences de l'eau ? Essai pour une politique franco-européenne de l'eau rénovée. Paris, Johanet.

Kaika, M. (2004). Water for Europe: the Creation of the European Water Framework Directive. Managing Water Resources, Past and Present. J. Trottier and P. Slack. Oxford, Oxford University Press.

Kaika, M. and B. Page (2003). "The EU water framework directive: part1 European policy making and the changing topography of lobbying." European environment 13: 314327.

Kallis, G. and D. Butler (2001). "The EU water framework directive: measures and implications." Water Policy 3: 125-142.

Kallis, G. and P. Nijkamp (2000). "Evolution of EU water policy: A critical assessment and a hopeful perspective." Zeitschrift für Umweltpolitik und Umweltrecht (ZfU)(3): 301335.

Liefferink, D. and M. Skou-Andersen (2005). Strategies of the 'Green' Member States in the EU Environmental Policy-making. Environmental Policy In The European Union. A. Jordan, Earthscan: 49-66.

Lodge, J. (1989). Environment: Toward a Clean Blue-Green EC. The European Community and the Challenge of the Future. J. Lodge. London, Pinter. 
Löfstedt, R., D. Vogel, O. Renn, D. Slater and M. Rogers (2001). "The changing character of regulation: a comparison of Europe and the United States." Risk Analysis 21(4): 5778.

Lund, J. R. (2007). Envisioning Futures for the Sacramento-San Joaquin Delta, Public Policy Institute of California.

Meadows, D. and Club de Rome (1972). Halte à la croissance ? Rapport Meadows, Fayard.

Moog, O. and A. Chovanec (2000). "Assessing the ecological integrity of rivers: walking the line among ecological, political and administrative interests." Hydrobiologia(422/423): 99-109.

Moss, T. (2003). Solving Problems of "Fit" at the Expense of Problems of "Interplay"? The Spatial Reorganisation of Water Management following the EU Water Framework Directive. draft. Erkner, Institute for Regional Development and Structural Planning.

Mostert, E. (2003). "The European Water Framework Directive and water management research " Physics and Chemistry of the Earth, Parts A/B/C 28(12-13): 523-527

Page, B. and M. Kaika (2003). "The EU water framework directive: part2 policy innovation and the shifting choregraphy of governance." European environment 13: 328-343.

Pinton, F. (2001). "Conservation of Biodiversity as a European Directive: The Challenge for France." Sociologia Ruralis 41(3).

Porta, J. (2006). La réalisation du droit communautaire. Essai sur le gouvernement juridique de la diversité. Thèse pour le doctorat en droit privé UFR Sciences juridiques, administratives et politiques. Paris, Université Paris X - Nanterre: 881.

Richardson, J. (1994). "EU water policy: uncertain agendas, shifting networks and complex coalitions." Environmental Politics 3(4): 139-167.

Richardson, J. L. (1980). "Commentary: The Organismic Community: Resilience of an Embattled Ecological Concept." BioScience 30(7): 465-471.

Roche, P.-A., G. Billen, J.-P. Bravard, H. Décamps, D. Pennequin, E. Vindimian and J.-G. Wasson (2005). "Les enjeux de recherche liés à la directive cadre européenne sur l'eau." C.R. Géoscience 337: 243-267.

Rootes, C. (1999). Environmental Movements: Local, National and Global, Routledge

Sax, J. L., B. H. Thompson Jr, J. D. Leshy and R. H. Abrams (2006). Legal control of water resources. Cases and materials. Fourth Edition. St Paul, MN, Thomson West.

Vogel, D. (1997). "Trading up and governing across: transnational governance and environmental protection." Journal of European Public Policy 4(4): 556 - 571.

Vogel, D. (2005). The Hare and the Tortoise Revisited: The New Politics of Consumer and Environmental Regulation in Europe. Environmental Policy In The European Union. A. Jordan, Earthscan: 225-252. 